\title{
Tverrprofesjonell samarbeidslæring økte bevisstheten om egen profesjon
}

Sykepleier- og ergoterapistudenter samarbeidet tett da de hadde praksis på sykehuset i Gjøvik. De lærte om hverandres yrker, men fikk også økt innsikt i sitt eget.

\section{Elin Stikbakke}

Høgskolelektor

Institutt for helsevitenskap, Norges teknisk-naturvitenskapelige universitet, Gjøvik

Camilla Hellum

Spesialergoterapeut

Ergoterapiavdelingen, Sykehuset Innlandet, Divisjon Gjøvik

Sigrid Lund

Hovedveileder og sykepleier

Medisinsk avdeling 2 AB, Sykehuset Innlandet, Divisjon Gjøvik

Stine Mamelund

Hovedveileder og sykepleier

Medisinsk avdeling 2 AB, Sykehuset Innlandet, Divisjon Gjøvik

Rønnaug Svalund

Spesialergoterapeut

Ergoterapiavdeling, Sykehuset Innlandet, Divisjon Gjøvik

Ingrid Nyborg

Spesialergoterapeut og ph.d. kandidat

Ergoterapiavdelingen, Sykehuset Innlandet, Divisjon Gjøvik 


\section{Hovedbudskap}

Et pilotprosjekt innen tverrprofesjonell samarbeidslæring (TPS) ble gjennomført ved Medisinsk avdeling ved Sykehuset Innlandet i Gjøvik, i samarbeid med sykepleier- og ergoterapiutdanningene ved NTNU i Gjøvik. Gjennom samarbeid om å gi helsefaglig bistand til pasienter lærte studentene om egen profesjon og andres profesjon gjennom ulike perspektiver og tilnærminger, roller og oppgaver. Studentene samarbeidet bedre når de fikk erfare hvordan roller og oppgaver kunne utfylle hverandre til det beste for pasienten. De positive erfaringene etter pilotprosjektet førte til at TPS-modellen etableres som læringsaktivitet også i kommende praksisperioder i sykehuset.

Ifølge samhandlingsreformen kan tverrfaglige team bli bedre til å samarbeide om pasientbehandling i helsetjenestene og samhandling på tvers av organisatoriske skillelinjer (1). Kunnskapsdepartementet $\varnothing$ nsker at studenter skal erfare tverrprofesjonelt samarbeid før de kommer ut i yrkeslivet (2). Yrkesutøvere som har utviklet evne til å kommunisere og samarbeide på tvers, vil gi et bedre og mer helhetlig tjenestetilbud til pasientene $(1,2)$. Tverrprofesjonell samarbeidslæring (TPS) er en læringsform som skal forberede helsefaglige bachelorstudenter til yrkesut $\varnothing$ velse.

Tverrprofesjonell samarbeidslæring i utdanningen innebærer at studenter fra ulike profesjonsutdanninger lærer om, av og sammen med hverandre. Studentene trenger kunnskap om relasjoner, strukturer og samspill for å kunne forstå hvordan samarbeid organiseres til det beste for pasienten (2).

\section{Hva er TPS?}

- Tverrprofesjonell samarbeidslæring (TPS) er en læringsform der studenter fra ulike profesjonsutdanninger lærer sammen. De får innsikt i andres kompetanse og dermed også bedre forståelse av egen kompetanse.

- Rolleforståelse og evne til samhandling er sentrale mål.

- TPS bør i hovedsak gjennomføres ved bruk av felles praksisperioder, men også i prosjektoppgaver og lignende.

- Innføring av TPS vil utgjøre en felles velferdsfaglig kompetanseplattform som sikrer bredt orienterte grunnutdanninger. TPS vil styrke studentenes evne til tverrfaglig samarbeid når de kommer ut i yrkesfeltet (2). 


\section{Økt forståelse for fagene}

En læringsaktivitet innenfor TPS er shadowing

(skyggepraksis), som vil si å følge en ansatt fra en annen

faggruppe og samarbeide i ulike pasientsituasjoner og møter i

helseteamet (3). Studentene i denne studien erfarte å få $\varnothing \mathrm{kt}$

forståelse for egne og andres fag, at samarbeidet hadde

betydning for å forstå pasientens rehabiliteringsbehov, og at

oppfølgingen fra veilederne var viktig for læring (3).

\section{$\equiv$ «Studentene i denne studien erfarte å få $\emptyset \mathrm{kt}$ forståelse for egne og andres fag.»}

Sykepleier-, ergoterapeut- og vernepleierutdanninger i

Hedmark og Oppland unders $\varnothing$ kte hvilket læringspotensial som kunne ligge i TPS, og utviklet en modell som ble testet i kommunehelsetjenesten (4). Studentene uttalte at de erfarte en personlig utvikling fra «prøvekanin til pioner», og at det var spesielt varighet, felles arbeidskrav og refleksjon som framsto som viktige forutsetninger for læringen.

Felles arbeidskrav og konkrete læringsaktiviteter knyttet til felles pasienter var viktig for læring hos alle tre faggruppene. Veilederne hadde en viktig funksjon som tilretteleggere for læringsaktiviteter og refleksjon, mens studentene i hovedsak lærte av og med hverandre (4).

Som praksisveiledere har forfatterne av denne artikkelen over flere år tilfeldig paret sykepleie- og ergoterapistudenter for læring i tverrfaglig samarbeid. Vi så at TPS-modellen kunne overføres til klinisk praksis i spesialisthelsetjenesten, og artikkelen beskriver hvordan vi på systematisk vis prøvde ut denne modellen.

\section{Metode}

Vår tilnærming er fenomenologisk-hermeneutisk ved at vi anser at erfaring ligger implisitt i situasjonen, og i fortellingen om situasjonen. Det å fortelle sin historie med egne ord, her i refleksjonsnotater og fokusgruppeintervjuer, kan potensielt bringe deltakerne fra et ubevisst nivå til ny praksis, nye innsikter og muligheter $(5,6)$.

\section{Deltakere}


Deltakere i prosjektet var fire sykepleierstudenter og fire ergoterapistudenter på andre års studie ved NTNU i Gjøvik. Som veiledere var to sykepleiere hvorav en med formell kompetanse i veiledning, en lektor fra sykepleierutdanningen og tre ergoterapiveiledere i praksis, hvorav en ph.d.-kandidat og prosjektleder.

\section{Gjennomføring av TPS}

Studentene ble introduserte for hverandre i et innledende lunsjmøte der prosjektet ble presentert. To skriftlige arbeidskrav var individuelle notat der studentene reflekterte over egen og den andre yrkesgruppens funksjon før og etter TPS.

I notatene reflekterte studentene over eventuelle endringer i oppfatning av egen og den andres profesjon. Dersom det ikke hadde foregått endringer i oppfatning, beskrev studentene hvordan egne oppfatninger hadde blitt bekreftet.

Det praktiske arbeidskravet var at studentene sammen valgte en pasient som de skulle gi helsefaglig bistand til. Studentene skulle foreslå kartlegging- og behandlingstiltak til praksisveiledere og få bekreftelse før de iverksatte tiltakene. Studentene deltok i avdelingens ordinære forum for tverrfaglig samarbeid, og de kontaktet veilederne ved behov.

Prosjektet foregikk i enhet for hjerneslag og geriatri i Akuttmedisinsk avdeling. Pasientene kjennetegnes ved komplekse helseproblemer, og helsepersonellet har lang erfaring med tverrfaglig samarbeid og veiledning av studenter i praksis. Daglig gjennomføres tverrfaglige møter med sykepleiere, terapeuter og leger.

\section{$\equiv$ «Ergoterapeutenes hverdag er uforutsigbar.»}

Ergoterapeutenes hverdag er uforutsigbar og styres av henvisninger fra avdelingen med varierende kompleksitet i problemstillingene. Sykehusavdelingen kjennetegnes ved høyt tempo, og sykepleiernes hverdag er forutsigbar travel.

\section{Datainnsamling}

Fokusgruppeintervju ble valgt for å fange erfaringer relatert til interaksjon mellom deltakere i prosjektet (6). Det ble satt av 60 minutter til hvert intervju. Refleksjonsnotater og referater fra fokusgruppeintervjuer utgjorde datamaterialet. 
Intervjuguiden hadde hovedspørsmålet: Hvordan er dine opplevelser og erfaringer med TPS i sykehuspraksis?

Observasjoner, læring om egne oppgaver i samspillet med den andre, begrepene omsorg og rehabilitering, kommunikasjon, ansvar og organisering var stikkord fra dette møtet, og ble inkludert i intervjuguiden.

\section{Dataanalyse}

Vi analyserte datamaterialet ved å identifisere temaer på en systematisk måte gjennom naiv lesning og gruppering av meningsenheter til temaer (6). På bakgrunn av analysen tematiserte og ordnet vi datamaterialets meningsinnhold. Både analyse og refleksjoner foregikk underveis i datainnsamlingen.

Analysen var inspirert av kvalitativ innholdsanalyse og ble blant annet utført ved at alle forfatterne deltok i konsensusdrøftinger (8).

\section{Resultat}

Studentene samarbeidet om å gi helsefaglig bistand til seks pasienter i fire dager, fordelt over fjorten dager. De deltok i rapporter, tverrfaglige møter, nevrologisk tilsyn og legevisitt.

Studentene gjennomførte pasientsamtaler med sykepleie- og ergoterapiperspektiv. Studentene utførte sykepleieoppgaver som NEWS-målinger, blæreskanning, måling av blodsukker, administrering av insulin, føring av slagkurve og innhenting av komparentopplysninger (sammenliknede opplysninger).

Studentene gjorde observasjoner i aktivitet og stellesituasjoner, ved av- og påkledning, ved forflytning og ved servering av måltider. I disse situasjonene hadde studentene begge profesjonenes ulike perspektiv. De gjennomførte også ergoterapeutiske kartleggingssamtaler, kjøkkenobservasjoner og ulike kognitive skrivebordstester.

Refleksjonsnotatene før og etter TPS viste en forskjell i oppfatning av de ulike profesjonenes roller og oppgaver. I førnotatene refererte studentene til teori, mens i notatene som ble skrevet etter observasjonene, refererte de hovedsakelig til erfaringer og ferdigheter relatert til person, profesjon og tverrprofesjonelt samarbeid med pasienten. 
Prosjektets resultater presenteres gjennom følgende tre temaer: å lære sin rolle i tverrprofesjonelt samarbeid, ulike perspektiver og ulik tilnærming og organisering av TPS i sykehus.

\section{Å lære sin rolle i tverrprofesjonelt samarbeid}

Ergoterapistudentene forteller at sykepleierstudentene får et bilde av hvordan pasientene har det ved at de arbeider geografisk tettere på pasientene og observerer pasientene gjennom hele døgnet.

Sykepleierstudentene får viktig informasjon gjennom å re senger og følge med på vitale funksjoner, effekt av medikamenter, næringsinntak og vekt. Sykepleierstudentene skårer også fallskjemaer og innhenter komparentopplysninger. Alt dette gir viktige opplysninger til de andre faggruppene, ifølge ergoterapistudent.

Sykepleierstudenter oppfattet at ergoterapistudentenes rolle og oppgave er å kartlegge pasientens fysiske og kognitive funksjon, for å kunne tilrettelegge best mulig for pasienten i hverdagen hjemme.

En sykepleierstudent sa:

«En ergoterapeut kartlegger hva en pasient klarer selv, og hva som er viktig i livet til pasienten. De arbeider for at pasientene skal mestre aktiviteter i hverdagen.»

Ifølge sykepleierstudentene kan ergoterapifokus blant annet være pasientens gripeevne, tempo og hensiktsmessig plassering av kroppen i forhold til aktuell aktivitet. Sykepleierstudentene erfarte at ergoterapistudenter bruker fagbegreper som beskriver hvordan pasienter gjennomfører en aktivitet, og at ergoterapistudenter graderer pasientens selvstendighet.

I refleksjonsnotat etter TPS viser sykepleierstudentene kunnskap om at kartleggingsverktøyet Ergoterapi Virksomhetsbasert Aktivitetsanalysesystem (EVA) gir oversikt over prosessferdigheter, motoriske ferdigheter og kommunikasjons- og interaksjonsferdigheter.

En sykepleierstudent sa: 
«Som sykepleier tenker du ikke over de samme tingene som en ergoterapeut gjør. De ser jo på hvordan pasienten mestrer daglig aktivitet. Det handler om å legge til rette for hverandres fag, slik at en pasient på sykehus kan opprettholde sine ferdigheter.»

En sykepleierstudent fortalte at hun tilpasset sin tilnærming til pasientene i løpet av TPS-perioden. Når hun stelte og kledde på pasientene, tilrettela hun slik at pasienten selv kunne utføre mer av stellet og påkledningen.

Sykepleierstudenten reflekterte også over at sykepleie har perspektiver som:

«Vi sørger for at for eksempel dusjing blir gjennomført samtidig som vi observerer respirasjon, sirkulasjon, sår, ødem, infeksjon.»

TPS som læringsaktivitet i sykehus kan gi en innføring i egen og den andres profesjonsrolle i tverrprofesjonelt samarbeid i klinisk praksis. At etterrefleksjonene relaterer til erfaringer og ikke til teori som før-refleksjonene, forstår vi som at studentene gjennom samarbeid får personlig erfaring. De tilpasset praksis når de kjente til hvordan roller og oppgaver kunne utfylle hverandre til det beste for pasienten.

\section{Ulike perspektiver og ulik tilnærming}

Studentene fikk bevissthet om eget fag ved å observere, kommunisere og samarbeide tverrprofesjonelt. De erfarte at ulike perspektiver gjorde seg gjeldende i én og samme situasjon.

En sykepleierstudent sa:

«Ergoterapeut og sykepleier kan observere samme situasjon, men ut ifra faggruppen legges det også merke til andre ting som den andre faggruppen ikke ser. Ergoterapeuter kan for eksempel se ting som ikke en sykepleier kan se. Det kan være for eksempel en mistanke om en kognitiv svikt eller nedsatt kraft i en hånd.» 
Ergoterapistudentene reflekterte over at

sykepleierstudentene raskere gir fysisk assistanse når pasienten får problemer med for eksempel påkledning. Dette forklarte ergoterapistudenter med at sykepleierstudentene har kunnskap om at pasienten kan bli for sliten til å gjennomføre en hel aktivitet, og at sykepleiere legger vekt på at pasienten skal få stelt seg best mulig. Det å gi fysisk assistanse og begrepet omsorg ble knyttet sammen, og én forståelse var at det var samme sak.

En ergoterapistudent sa:

«Ergoterapeuter trekker seg litt tilbake akkurat der [påkledning] og vil heller at pasienten skal gjøre så mye som mulig selv. Ergoterapeuter gir ikke like mye omsorg til pasienten som en sykepleier, føler jeg.»

En annen forståelse var at mye fysisk assistanse var uttrykk for mye omsorg, og en ergoterapistudent sa:

«Inntrykket jeg har fått, er at sykepleiere vil hjelpe pasienten så mye som mulig for å gi god pleie og omsorg.»

En annen refleksjon fra en sykepleierstudent var at ergoterapistudenter viser omsorg gjennom tilrettelegging for selvstendighet og opplevelse av mestring. Som læringsaktivitet i sykehus kan TPS synliggjøre for studentene at ulike perspektiver gjør seg gjeldende, og hvordan dette kan komme til uttrykk i profesjonenes tilnærming til pasientene.

\section{Organisering av TPS i sykehus}

Praksisveilederne til både sykepleier- og ergoterapistudentene erfarte at tilretteleggingen av TPSpraksis var noe mangelfull fra deres side. Veilederne ga ansvaret for det innledende lunsjmøtet til studentene, men uten å klargjøre nærmere hvordan det kunne gjennomføres.

Alle studentene fikk avsatt god tid til å skrive refleksjonsnotater. Å velge felles pasient forgikk på avdelingens morgenrapport, der også veiledere deltok. Ved fravær av veileder innlemmet i pilotprosjektet deltok ergoterapiveileder og/eller sykepleiere i valg av pasient. Studentene foreslo kartleggings- og behandlingstiltak, og fikk bekreftelse fra veiledere før iverksettelse.

På tvers av profesjonene ble studentene veiledet på prosess og kommunikasjon, mens sykepleie- og ergoterapifaglig veiledning ble lite etterspurt. 


\section{«Sykepleierstudentene var opptatt av hvor mye ergoterapistudentene dokumenterte $\mathbf{i}$ pasientjournalen.»}

Sykepleierstudentene var opptatt av hvor mye ergoterapistudentene dokumenterte i pasientjournalen. Dokumentasjonen gjennomførte ergoterapistudentene på ergoterapikontoret, og de var dermed utilgjengelige for sykepleierstudentene, som i liten grad kunne forlate avdelingen. Veilederne diskuterte i sin fokusgruppe om studentene i større grad kunne ha samarbeidet om å dokumentere i pasientjournalen.

Veilederne erfarte at TPS-modellen var en fleksibel og effektiv pedagogisk tilnærming i sykehus, og via modellen lærte studentene de ulike profesjonenes perspektiver og tilnærming, roller og oppgaver i det å gi helsefaglig bistand.

\section{Diskusjon}

Resultatene viser at studentene gjennom samarbeid erfarte ulike måter å tilnærme seg pasienten på og ulikheter i å identifisere dilemmaer i tilnærming til pasienter: Hvor store krav om egeninnsats er passende å gi til en pasient i rehabiliteringsprosess?

Denne problemstillingen drøftes i Melding til Stortinget 29 (2012-2013), hvor det presiseres at omsorgstjenestene har sin styrke innenfor behandling og pleie, men omsorgstjenestene vil i framtida måtte styrke rehabilitering, aktivitet og deltakelse (8).

Når studentene i vår studie problematiserte begrepet omsorg, relaterte de sin forståelse av egen og den andres profesjon. Vi forsto dette som at studentene gjennom TPS lærte om sitt eget og den andres fag ved å speile seg i hverandres praksis. Ifølge Kunnskapsdepartementet utvikles yrkesidentitet gjennom læring om egne oppgaver i samspillet med den andre, noe som samsvarer med både Kristensen og medarbeidere (3) og Dolva og medarbeidere (4).

Når det gjelder faglig veiledning, viser vår studie at praksisveiledernes rolle var å være tilretteleggere av felles læringsaktiviteter. Veilederne erfarte mye tilrettelegging, men lite faglig veiledning. Denne rolleforståelsen synes å være i samsvar med Dolva og medarbeidere (4), mens Kristensen og medarbeidere understreker nødvendigheten av veiledning (3). 
Læringsaktivitetene var studentsamarbeid henholdsvis ved å gi helsefaglig bistand til pasient (4), og shadowing av ansatte fra en annen faggruppe (3). Våre resultater viser at før- og etter refleksjonsnotatene endret seg fra å referere til teori til å referere til egne erfaringer.

Kristensen og medarbeidere (3) fant at studentene fikk mer informasjon om hverandres kompetanse, mens vårt pilotprosjekt fant at studentene fikk erfaring med egen og den andres kompetanse. Dette samsvarer med Dolva og medarbeidere (4); gjennom å lære av, med og om, erfarer studenter å få ny og økt innsikt i hverandres kompetanse og ferdigheter.

\section{Konklusjon}

TPS-modellen viste seg å være anvendbar pedagogikk også i sykehus. Samarbeidslæring ga sykepleier- og ergoterapistudenter mulighet til å lære om profesjonenes ulike perspektiver, tilnærming, roller og oppgaver i å gi helsefaglig bistand til pasienter i avdelingen Enhet for slag og geriatri.

\section{三 «TPS-modellen viste seg å være anvendbar pedagogikk også i sykehus.»}

Praksisveilederne erfarte at TPS-modellen er fleksibel, og modellen innføres som fast innslag i liknende praksisperioder i sykehuset. Sykehusavdelingen er en kompleks praksisarena med høyt tempo, som gir god mulighet for TPS med geografisk nærhet til alle profesjoner og rikelig tilgang på ulike problemstillinger hva angår helse og sykdom. Det vil være relevant å prøve ut TPS-modellen i spesialisthelsetjenesten generelt.

\section{Referanser}

1. St.meld. nr. 47 (2008-2009). Samhandlingsreformen - Rett behandling - på rett sted - til rett tid. Oslo: Helse- og omsorgsdepartementet; 2009. Tilgjengelig fra: http://www.regjeringen.no/nb/dep/hod/dok/regpubl/stmeld/20 o8-2009/stmeld-nr-47-2008-2009-.html?id=567201 (nedlastet 20.06.2019).

2. Meld. St. 13 (2011-2012). Utdanning for velferd. Samspill i praksis. Oslo: Kunnskapsdepartementet; 2012. Tilgjengelig fra: https://www.regjeringen.no/no/dokumenter/meld-st-1320112012/id672836/sec1 (nedlastet 20.02.2019). 
3. Kristensen DV, Flo J. Tverrprofesjonell veiledning av helsefagstudenter i praksis. Tidsskrift for psykisk helsearbeid. 2014;11(04):317-26.

4. Dolva A-S, Johansen AS, Lindstad M $\varnothing$, Martinsen FR, Steinseth EB, Wangensteen S. Studenters erfaringer med tverrprofesjonell samarbeidslæring: Fra «prøvekanin» til pioner. Tidsskrift for omsorgsforskning. 2017;3(03):216-26.

5. Mattingly C. Healing dramas and clinical plots. The narrative structure of experience. Los Angeles: University of California Press; 1998.

6. Brinkmann S, Kvale S. InterViews: learning the craft of qualitative research interviewing. Thousand Oaks, California: Sage; 2015 .

7. Elo S, Kääriäinen M, Kanste O, Pölkki T, Utriainen K, Kyngäs H. Qualitative content analysis: A focus on trustworthiness. SAGE Open. 2014;4(1).

8. Meld. St. 29 (2012-2013). Morgendagens omsorg. Oslo: Helse- og omsorgsdepartementet; 2013. Tilgjengelig fra: https://www.regjeringen.no/no/dokumenter/meld-st-2920122013/id723252/ (nedlastet 20.06.2019). 